\title{
Randomized trial of total fundoplication and fundal mobilization with or without division of short gastric vessels. A short-term clinical evaluation ${ }^{1}$
}

\author{
Estudo prospectivo e randomizado da fundoplicatura total e mobilização do fundo \\ gástrico com ou sem secção dos vasos gástricos curtos. Resultados de avaliação \\ clínica em curto prazo
}

\author{
José Francisco de Mattos Farah², José Carlos Del Grande ${ }^{3}$, Alberto Goldenberg 3 , Júlio César Martinez ${ }^{4}$, Renato \\ Arione Lupinacci ${ }^{5}$, Jacques Matone ${ }^{6}$ \\ 1. Research performed at Gastrointestinal Division, Department of Surgery, Federal University of São Paulo (UNIFESP) and General Surgery Division, \\ State Server Public Hospital (HSPE), São Paulo, Brazil. \\ 2. PhD, Gastrointestinal Surgery, Department of Surgery, UNIFESP and Chief of General Surgery Division, HSPE, São Paulo, Brazil. \\ 3. PhD, Associate Professor, Gastrointestinal Division, Department of Surgery, UNIFESP, São Paulo, Brazil. \\ 4. PhD, Gastrointestinal Surgery, Department of Surgery, UNIFESP, São Paulo, Brazil. \\ 5. PhD, Director of General Surgery Division, HSPE, São Paulo, Brazil. \\ 6. Fellow PhD degree, Gastrointestinal Surgery, Department of Surgery, UNIFESP, São Paulo, Brazil.
}

\begin{abstract}
Purpose: Evaluate short-term results after fundoplication procedure, concerning the division of short gastric vessels. Methods: A prospective randomization of 90 patients with indication for hiatoplasty and total fundoplication with fundus mobilization was performed. They were divided into two groups: no SGV division (group A, $n=46$ ) and with SGV division (Group B, n=44), although in both groups the gastric fundus was mobilized to perform a floppy valve. Early outcome with clinical follow up (1 year) was observed. Results: Both groups were similar regarding preoperative parameters and severity of gastroesophageal reflux disease (GERD). No difference in morbidity was observed during hospital stay. Nevertheless, the median operating time was 80,2 minutes in group A and 94,1 minutes ( $\mathrm{p}=0,021)$ in Group B. Transitory dysphagia during the first year was significantly lower in group B (46,6\% versus $23,2 \%, p=0,012)$. However, in 12 months clinical outcome was similar in both groups (clinical symptoms of GERD, persistent dysphagia and reoperations). Conclusion: There was no improvement in routine division of SGV in total fundoplication procedure when the gastric fundus was mobilized.
\end{abstract}

Key words: Fundoplication. Gastroesophageal reflux. Surgery. Clinical trials.

\section{RESUMO}

Objetivo: Comparar os resultados imediatos e curto prazo segundo a secção ou não dos vasos gástricos curtos. Métodos: Estudo prospectivo randomizado com 90 pacientes selecionados em dois grupos: 46 (grupo A) sem secção e 44 (Grupo B) com secção dos vasos gástricos curtos, seguidos de hiatoplastia e fundoplicatura total por laparoscopia. Analisaram-se os resultados até um ano de pós-operatório. Resultados: Os dois grupos eram homogêneos quanto aos critérios demográficos e aos relacionados á doença do refluxo gastroesofágico. Não houve diferença quanto á morbidade ou tempo de internação, porém o tempo cirúrgico foi maior no Grupo B (80,2 minutos contra 94,1 minutos, p=0,021). Disfagia transitória foi mais freqüente no Grupo A (46,6\% versus 23,2\%,p=0,012), porém na avaliação final de primeiro ano do pós-operatório não existindo diferença quanto á disfagia persistente, reoperação ou recidiva. Conclusão: Não houve melhora quando da secção rotineira para a mobilização do fundo gástrico para a realização da fundoplicatura total por laparoscopia.

Descritores: Fundoplicatura. Refluxo gastroesofágico. Cirurgia. Ensaios clínicos. 


\section{Introduction}

Recently, total fundoplication followed by esophageal hiatoplasty under laparoscopic technique has been the most common surgical treatment for Gastroesophageal Reflux Disease (GERD) ${ }^{1,2}$. The surgical technique was described by Nissen in 1956 and, since then, some modifications of the original method were reported, in order to decrease side effects as dysphagia, gas bloating, and difficulty in vomiting and so on. The most important modifications were described in the pre-laparoscopy era. Donahue et al. ${ }^{3}$ proposed the floppy fundoplication and DeMeester et al. ${ }^{4}$ observed that a two centimeters valve was enough for the success of the operation (short fundoplication). This last group suggested a routine short gastric vessels (SGV) division, including gastric adhesions as well as the pancreatic-gastric vessels division, so as to achieve a short and floppy fundoplication. Randomized trial during laparotomy era showed similar results with this technique but a higher hiatal hernia long-term incidence after SGV division ${ }^{5,6}$. After the development of laparoscopic access described by Geagea ${ }^{7}$ and Dallemagne et al. ${ }^{8}$, the first reports suggested the routine SGV division to reduce postoperative dysphagia ${ }^{9,10,11}$. However, other researches did not had the same results ${ }^{12,13,14,15}$. The randomized clinical trials (RCT) during laparoscopic era present now different standards of technique: the mobilization extension, number of divided vessels and the technique to make those divisions. Watson et al. ${ }^{16}$, used metallic staples; other techniques included monopolar cauterization and harmonic scalpel ${ }^{17,18}$. When the SGV were not divided, the anterior wall of gastric fundus was used for the fundoplication, and not the posterior wall ${ }^{16,17,18}$. A metanalysis published by Catarci et al. ${ }^{19}$ concluded that the routine division of SGV had no advantage. However, criticism was made to this study, concerning specific aspects related to the gastric fundus mobilization such as: instruments, experienced surgical team and the number of different surgeons performing the procedure ${ }^{20}$. The aim of this study was to compare the results of total fundoplication and gastric mobilization with and without SGV division, after a one-year follow-up

\section{Methods}

We included 122 adult patients with indication for surgical treatment of GERD in the Gastrointestinal Division of the Federal University of Sao Paulo (UNIFESP) and the General Surgery Division of the State Server Public Hospital (HSPE). The study was approved by the Ethics Committee in Research of the Federal University of Sao Paulo. Thirty two patients were excluded from the study due to the following reasons: esophageal body dysfunction characterized by low pressure on manometric study $(<30$ $\mathrm{mmHg}$ ) and the presence of more than $20 \%$ of nonperistaltic waves; hard stenosis, unable to dilate; Barrett esophagus with complications as dysplasia, ulcers and stenosis; short esophagus; paraesophageal hernia; previous surgery in the gastroesophageal area; and patient denial to participate in the research. As a result, this studied was carried out with 90 patients, mean age of 46,3 years, composed by $53,3 \%$ male and $46,7 \%$ female patients. Ten patients $(11,1 \%)$ underwent cholecystectomy at the same procedure time. The patients were randomized in two groups: Group A (without SGV division) and Group B (with SGV division). The study was a clinical trial with intention to treat method; thus the patients remained in the same group as previously allocated, independently on the real treatment received.

\section{Pre-operative evaluation}

GERD was diagnosed based on typical clinical symptoms relieved after proton pump inhibitor use, as well as endoscopic findings of erosive esophagitis. When different presentations were noted, a 24 hour pHmetric exam was performed. Symptoms were graded regarding severity and occurrence: grade 0 - asymptomatic; grade 1 - occasional complaint without specific medical therapy; grade 2 frequent complaints, with continuous medical therapy to relieve; grade 3 - no relieve even after medical therapy and recommendations. Dysphagia symptom was also graded21: grade 0 - no dysphagia; grade I - mild dysphagia; grade II - slight obstruction, with liquid intake necessary to relieve; grade III - progressive dysphagia for solid seeking medical care, hospital stay or total obstruction. All patients underwent endoscopy and esophageal manometric study. Endoscopic findings were graded concerning the degree of esophagitis and its complications, following Savary-Miller modified classification.

\section{Surgical technique}

All procedures were performed by the same surgeon, with similar dissection and hiatoplasty time in both groups. The abdominal esophagus was dissected and 5,0 cm extension was isolated together with vagus nerve. The hiatoplasty was done with " $\mathrm{X}$ " 2.0 non-absorbable stitches, tightening the hiatus so as to allow a $10 \mathrm{~mm}$ instrument throughout the hiatus.

\section{Gastric fundus mobilization - Group A - no $\underline{\mathrm{SGV} \text { division. }}$}

The gastric fundus mobilization started with dissection of the left arm of the right hiatal arm, from the right side of the esophagus isolated and pulled to the left, in order to find a low irrigated area. This presentation was achieved with pulling the hiatus and contra-traction with exposition of the posterior wall of gastric fundus. The vessels that communicate the gastric fundus with the inferior phrenic vessels were divided routinely (Figure 1). Most of the time, the mobilization was completed by the left side, with 
incision of phrenic-esophageal tissue and the adhesions near the superior area of the spleen.

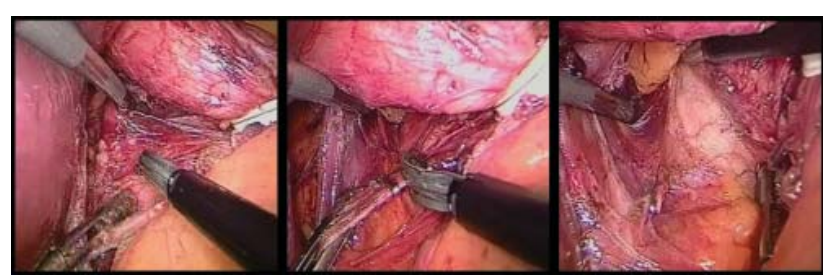

FIGURE 1 - Gastric fundus dissection close to the diaphragm (a) and vessels division (b) with mobilization of the posterior wall of gastric fundus (c) on the right side of esophagealgastric transition

\section{$\underline{\text { Gastric fundus mobilization - Group B - with SGV }}$ division}

SGV were divided by the use of harmonic scalpel from the inferior splenic area following the gastro-splenic omentum in cranial direction until the esophago-gastric transition (EGT). The retroperitoneal cavity was opened after division of the initial gastric vessels and following the great gastric curvature, in order to proceed division of all SGV, with complete liberation of the gastric wall from the splenic vessels and retroperitoneum, through the pancreatic-gastric vessels division (Figure 2).

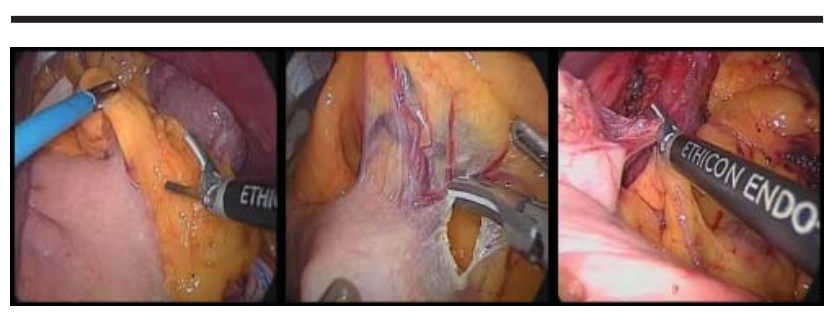

FIGURE 2 - SGC division, from theinferior splenic area(A and B) and the gastric-pancreatic vessels (C)

\section{Fundoplication}

The anti-reflux valve was performed with the tension-free gastric fundus placed on the right side of the esophagus (no need to use instrument for this traction Figure 3) and without torsion of the gastric fundus (shoe shine maneuver). The fundoplication had 2-3 centimeters, with three 2.0 non-absorbable stitches. The proximal and the distal stitches were applied to the gastric wall and the middle one was applied to the gastric wall together with the esophageal wall, to avoid migration of the valve. The procedure was performed with calibration of a $10 \mathrm{~mm}$ instrument, to confirm the floppy valve (Figure 4).

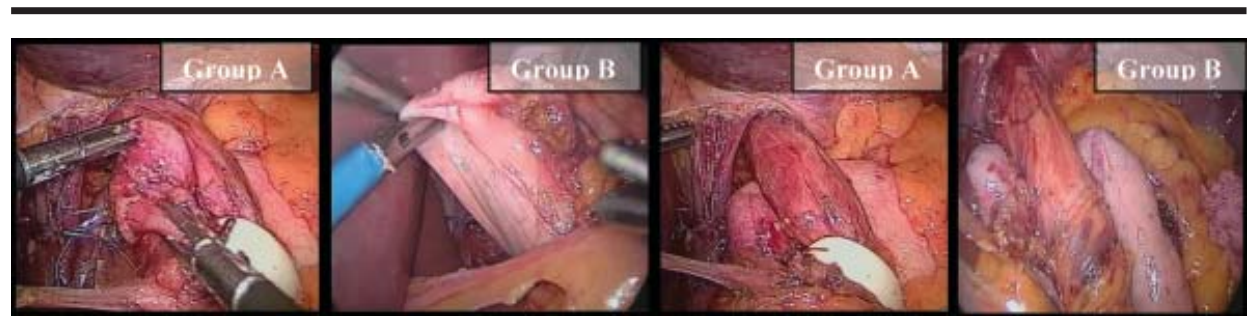

FIGURE 3 - Gastric fundus posterior wall mobilized (A and B) and the positioning of the gastric fundus without instrument fixation ( $C$ and $D)$

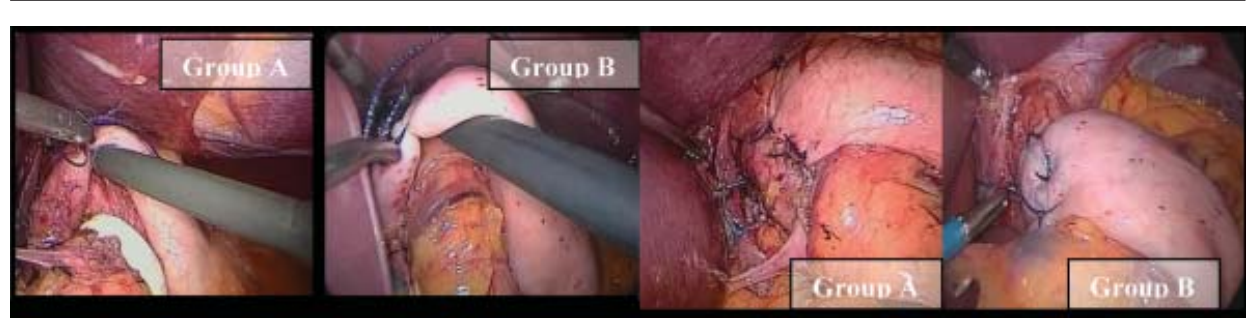

FIGURE 4 - Fundoplication: calibration with 10 mm instrument (A and B) and final appearance (C and D) 


\section{Postoperative care}

Patients were kept with nasogastric tube for eight to 12 hours. Liquid diet was given on the first postoperative day and the progression to solid food after three to four weeks after the procedure. Excessive physical exercises were prohibited for three months. Patients were evaluated by the surgeon on postoperative days: seven, 30, 90, 180 and after one year of the surgical procedure.

\section{Evaluation of intra-operative results}

The following issues were evaluated: intra-operative complications; significant bleeding (need to remove blood and clots with suction); visceral perforations or lesions; operative time; conversion to open technique; change in the beginning planned technique.

Evaluation of immediate post-operative results (until $30^{\circ}$ P.O.)

Evaluated concerning morbidity (general and specific complications); hospital stay length; and mortality.

\section{Results evaluation after one year}

The patients were evaluated during the first year (three months, six months and one year) regarding the presence of dysphagia and graded according to Gotley et al. ${ }^{21}$ from 0 to 3. Dysphagia was considered transitory until 90 days and continuous if lasting longer than 12 months postoperatively. The recurrence of symptoms of GERD and the need for medical therapy was considered in the postoperative evaluation.

\section{Statistical analysis}

The categorical variables were compared between the groups using non-parametric Chi-square test and Fisher's exact test. Regarding numeric variables, the t-Student test was applied when normality supposition was satisfied or the Mann-Whitney non-parametrical when this supposition was not satisfied. The normality of data was verified using the Kolmogorov-Smirnov test. The significance level of the tests were $\alpha=0,05$.

\section{Results}

The 90 patients enrolled in this trial, 46 were allocated in Group A (no SGV division) and 44 patients in group B (with division). Tables 1 and 2 describe demographic, clinical, endoscopic and manometrical findings. No significant difference was found between both groups concerning the presence of hiatal hernia, complications from esophagitis, Barrett esophagus and manometric data of lower esophageal sphincter pressure (LES). As regards to intestinal metaplasia, eight patients had long Barrett esophagus and seven patients presented short Barrett esophagus.

TABLE 1 - Characteristics of patients enrolled in the trial

\begin{tabular}{lccl}
\hline & $\begin{array}{c}\text { Short vessel intact } \\
(\mathrm{n}=46)\end{array}$ & $\begin{array}{c}\text { Divided Short vessel } \\
(\mathrm{n}=44)\end{array}$ & p value \\
\hline Males/females & $24 / 22$ & $24 / 20$ & - \\
Age (years) & $47,4,+/-13,8(23-74)$ & $45,1+/-11,8(21-70)$ & $0,388 \mathrm{t}-\mathrm{S}$ \\
Body mass index & $26,4=/-4,0$ & $25,8+/-3,8$ & $0,481 \mathrm{t}-\mathrm{S}$ \\
Duration symptoms (mth) & $65,0+/-47,7$ & $59,2+/-45,5$ & $0,425 \mathrm{t}-\mathrm{S}$ \\
Endoscopic grade & & & \\
0 & 2 & 5 & \\
1 & 12 & 11 & \\
2 & 16 & 11 & \\
3 & 1 & 2 & \\
4 & 7 & 8 & $0,750 \mathrm{Q}$ \\
5 & 8 & 7 & $0,925 \mathrm{M}-\mathrm{W}$ \\
\hline total & 46 & $8,0+/-4,1$ & \\
\hline
\end{tabular}

Q: Chi-Square test; F: Fisher's exact test ; t-S: t-Student test; M-W: Mann-Whitney test; *: significant difference. 
TABLE 2 - Perioperative course

\begin{tabular}{lccc}
\hline & $\begin{array}{c}\text { Short vessel intact } \\
(\mathrm{n}=46)\end{array}$ & $\begin{array}{c}\text { Divided Short vessel } \\
(\mathrm{n}=44)\end{array}$ & p value \\
\hline Operative time (min) & $75,0+/-24,9(40-120)$ & $95,0+/-19,5(50-135)$ & $0,0045 \mathrm{t}-\mathrm{S}$ \\
Perioperative complication (\%) & $3(6,5)$ & $4(9,1 \%)$ & $0,710 \mathrm{~F}$ \\
Pneumothorax & 1 & 0 & \\
$<$ CO2 & 2 & 1 & \\
Bleeding & 0 & $0(0)$ & $\#$ \\
Study failure (\%) & $1(2,2)$ & 3 & \\
\hline
\end{tabular}

Q: Chi-Square test; F: Fisher's exact test ; t-S: t-Student test; M-W: Mann-Whitney test; *: significant difference. \# unable to perform.

\section{Intra-operative results}

The only significantly different data found was the mean surgical procedure duration (Table 2), being 80,2 minutes in group A against 94,1 minutes in group $\mathrm{B}$ $(p=0,0045)$. Seven $(7,7 \%)$ from the 90 patients developed intra-operative complications, three $(6,5 \%)$ in group A and four $(9,1 \%)$ in group $B$. No conversion to open surgery was necessary. However, in one patient from group A, it was not possible to perform the fundoplication without division of SGV (technique failure), that as carried out with no complications.

\section{Immediate postoperative results}

Seven patients presented low risk postoperative complications, with no difference between groups, with same hospital stay length (Table 3). There was no mortality rate and no re-intervention procedure was necessary.

One-year follow-up results

Dysphagia was related until three months postoperatively in 39 (43,3\%) patients (Table 4), more frequent in group A $(56,5 \%)$ than in group B $(29,5 \%)$, $\mathrm{p}=0,012$. After 6 months, this difference turned out to not to be statistically different between groups (six patients - three from group A and three from group B - complaint of dysphagia grade I or II). Severe dysphagia (grade III) was referred by three patients (two from group A and one from group B), with the need of endoscopic dilation to relieve symptoms. After one-year follow-up, one patient from each group had symptoms recurrence (Table 4).

TABLE 3 - Postoperative course

\begin{tabular}{lccc}
\hline & $\begin{array}{c}\text { Short vessel intact } \\
(\mathrm{n}=46)\end{array}$ & $\begin{array}{c}\text { Divided Short vessel } \\
(\mathrm{n}=44)\end{array}$ & p value \\
\hline Post. stay (days) & $2,6(2-5)$ & $2,8(2-4)$ & $1,0 \mathrm{t}-\mathrm{S}$ \\
Early complications & 4 & 3 & $\#$ \\
pulmonar & 1 & 1 & \\
gas bloat & 1 & 1 & \\
Incision & 2 & 1 & $\#$ \\
Study failure (\%) & $1(2,2)$ & $0(0)$ & \#
\end{tabular}

TABLE 4 - First year follow-up

\begin{tabular}{lccc}
\hline & $\begin{array}{c}\text { Short vessel intact } \\
(\mathrm{n}=46)\end{array}$ & $\begin{array}{c}\text { Divided Short vessel } \\
(\mathrm{n}=44)\end{array}$ & p value \\
\hline Food Impaction (\%) & $1(2,2)$ & $0(0)$ & $1.0 \mathrm{~F}$ \\
Early Disphagia (\%) & $26(56,5)$ & $13(29,5)$ & $0,012 \mathrm{Q}$ \\
Severe disphagia (\%) & $2(7,7)$ & $1(2,3)$ & $1,0 \mathrm{~F}$ \\
Dilataction (\%) & $2(4,3)$ & $1(2,3)$ & $1,0 \mathrm{~F}$ \\
Late disphagia (\%) & $3(6,5)$ & $3(6,8)$ & $1,0 \mathrm{~F}$ \\
Reflux synptoms (\%) & $1(2,2)$ & $1(2,3)$ & $1,0 \mathrm{~F}$ \\
\hline
\end{tabular}

Q:Chi-Square test; F: Fisher's exact test; t-S:t-Student test; M-W: Mann-Whitney test; *: significant difference.\# unable toperform 


\section{Discussion}

Routine division of SGV has been proposed since laparotomy era. Nevertheless, after the publications of laparoscopic technique to perform the fundoplication for the treatment of $\mathrm{GERD}^{7,8}$, the controversies regarding this issue remained. Furthermore, new technical details such as new instruments for a new surgery, learning curve on this new surgical practice, technical difficulties for the division of the SGV have been discussed. Some publications relating important and long-lasting dysphagia with the non-liberation of the gastric fundus through SGV division ${ }^{9,22,23}$. New techniques were described, as the fundoplication without SGV division to prevent such complication $^{24}$. The first randomized clinical trial in the laparoscopic era, concerning the routine division of SGV, showed that no manometric, endoscopic and clinical improvement was detected after one-year follow-up. However, in that study, seven different surgeons performed the procedures and different techniques (metallic staples) were used for the SGV division ${ }^{16}$. Another randomized trial evaluated 90 patients and found no difference comparing clinical outcome one-year after the surgical procedure ${ }^{17}$. Moreover, another study with 56 patients compared phmetric, manometric, endoscopic and contrast-enhanced radiography data and revealed no significant difference between groups. After 12 months, dysphagia and recovery from GERD were similar in both groups, although patients that underwent SGV division presented more gas bloating complaint ${ }^{18}$. However, none of the reported studies had a uniform technique of SGV division with harmonic scalpel (group B) and gastric fundus mobilization using posterior and anterior wall (group A) for the fundoplication, one of the most important differences of our study. Indeed in both groups we probably performed more extensive mobilization than others previous RCTs. The use of harmonic scalpel for SGV division has been advocated to be better than with the use of staples ${ }^{25,26}$. Another study compared the harmonic scalpel with the bipolar electrocautery and found no significant difference comparing intra and immediate postoperative aspects ${ }^{27}$. Despite the fact that we used the harmonic scalpel for SGV division in every procedure, this group had higher procedure duration. All three randomized clinical trials (RCT) also revealed longer procedure time in the SGV division groups ${ }^{16,17,18}$. We must emphasize that the extended gastric mobilization including division of all SGV and adhesions of the posterior wall as proposed by DeMeester et al.4 was reposted only in our study. The others described three to four SGV division, usually the most superior and no care was taken with adhesions and posterior vessels ${ }^{16,17,18}$. In our study, three patients developed no-significant bleeding during SGV division (no hemodynamic alteration, conversions and no transfusion required). Previous RCT reported important bleeding in seven patients, all after the use of metallic staples, requiring conversion in two cases and re- intervention in one16 and bleeding and re-operation ${ }^{17,18}$. These complications should have been avoided by the use of the harmonic scalpel. In one of our cases, we were unable to perform the fundoplication without SGV division (initial proposal), due to technical difficulties. Blomqvist et al. ${ }^{17}$ had the same situation and Watson et al.16 gave up dividing the SGV to shorten operation time due to clinical problems. The performance of the fundoplication with gastric body without SGV division may lead to anatomical and functional dysfunction. Some anatomical issue may be related to the necessity of SGV division to create a tension-free anti-reflux valve. The variations of gastric fundus determined the need to divide SGV28. Anyhow, the access to gastric fundus on the right side of the esophagus without SGV division had shorter operation time and was accomplished safely in almost every procedure. After oneyear follow-up, the results show that dysphagia was the main complaint. Transitory dysphagia was more common in the SGV division group, different from the previous RCT's $^{16,17,18}$. The exact reason for dysphagia remains unclear and may be related to patients past medical history or surgical technique details. DeMeester et al.4 proposed the use of large tube (48-50FR) inside the esophagus for calibration of the fundoplication to prevent transitory dysphagia. These findings were similar to the results of Patterson et al. ${ }^{29}$. Some authors advocate no advantages by this routine technique ${ }^{30}$, emphasizing the risk for perforation and severe complications related to these tubes ${ }^{29,31}$. We do not use this tube, but we double-check the gastric fundus floppy anti-reflux valve as described previously. Dysphagia definition, intensity and classification characterization may present variations. However, it may happen in the early postoperative period in more than $90 \%$ of patients, and this shall be considered to be normal and sometimes even desired $^{32}$. As regards to permanent dysphagia , we observed that this complaint was less common in both groups after six months, and the difference turned out to be not significant, as it was in early postoperative time. Six patients $(6,2 \%)$ presented with any dysphagia degree after one year (grade I and II, with no need for endoscopic dilation or medical therapy). No difference was found when comparing the severity of dysphagia, as dysphagia grade III was similar in both groups, as it was the need for endoscopic dilation and reoperation for this purpose. This observation matches with the literature. Permanent dysphagia was reported from $0 \%$ to $5 \%$ in analyzed series $2,33,34,35,36$. Finally, two patients presented GERD symptoms recurrence after one year. Still, these evaluations need long-term results.

\section{Conclusion}

Routine SGV division for gastric fundus mobilization and fundoplication did not prove to have any definitive advantage concerning clinical outcome one year after surgery. 


\section{References}

1. Fuchs KH, Breithaupt W, Fein M, Maroske J, Hammer I. Laparoscopic Nissen repair: indications, techniques and long-term benefits. Langenbecks Arch Surg. 2005;390:197-202.

2. Dallemagne B, Weerts JM, Markiewicz S, Dewandre JM, Wahlen C, Monami B, Jehaes C. Clinical results of laparoscopic fundoplication at ten years after surgery. Surg Endosc. 2006;20(1):159-65.

3. Donahue PE, Samelson S, Nyhus LM, Bombeck T. The floppy Nissen fundoplication. Arch Surg. 1985;120:663-8.

4. DeMeester TR, Bonavina L, Albertucci M. Nissen fundoplication for gastroesophageal reflux disease. Ann Surg. 1986;204(1):9-20.

5. Luostarinen MES, Koskinen M, Reinikainen P, Karvonen J, Isolauri JO. Two antireflux operations: floppy versus standard Nissen fundoplication. Ann Med. 1995;27:199-205.

6. Luostarinen MES, Isolauri JO. Randomized trial to study the effect of fundic mobilization on long-term results of Nissen fundoplication. Br J Surg. 1999;86(5):614-8.

7. Geagea T. Laparoscopic Nissen's fundoplication: preliminary report on ten cases. Surg Endosc. 1991;5(4):170-3.

8. Dallemagne B, Weerts JM, Jehaes C, Markiewicz S, Lombard R. Laparoscopic Nissen's fundoplication: preliminary report. Surg Laparosc Endosc. 1991;1(3):138-43.

9. Hunter JG, Swanstrom L, Waring JP. Dysphagia after laparoscopic antireflux surgery: the impact of operative technique. Ann Surg. 1996a;224(1):51-7.

10. Wu JS, Dunnegan DL, Luttmann DR, Soper NJ. The influence of surgical technique on clinical outcome of laparoscopic Nissen fundoplication. Surg Endosc. 1996;10:1164-70.

11. Leggett PL, Bissell CD, Churchman-Winn R, Ahn C. A comparison of laparoscopic Nissen fundoplication and Rossetti's modification in 239 patients. Surg Endosc. 2000;14(5):473-7.

12. Anvari M, Allen C. Prospective evaluation of dysphagia before and after laparoscopic Nissen fundoplication without routine division of short gastrics. Surg Laparosc Endosc Percut Tech. 1996;6(6):424-9.

13. Anvari M, Allen C. Laparoscopic Nissen fundoplication: two-year comprehensive follow-up of a technique of minimal paraesophageal dissection. Ann Surg. 1998;227(1):25-32.

14. Pessaux P, Arnaud JP, Ghavami B, Flament JB, Trebuchet G, Meyer C, Huten N, Champault G. Laparoscopic antireflux surgery: comparative study of Nissen, Nissen-Rossetti and Toupet fundoplication.
Surg Endosc. 2000;14:1024-7.

15. Felix VN, Yogi I, Perini M, Echeverria R, Bernardi C. Surgical treatment of the non-complicated gastroesophageal reflux: fundoplication without division of the short gastric vessels. Arq Gastroenterol. 2002;39(2):93-7.

16. Watson DI, Pike GK, Baigrie RJ, Mathew G, Devitt PG, Britten-Jones R. Prospective double-blind randomized trial of laparoscopic Nissen fundoplication with division and without division of short gastric vessels. Ann Surg. 1997;226(5):642-52.

17. Blomqvist A, Dalenback J, Hagedom C, Lunroth H, Hyltander A, Lundell L. Impact of complete gastric fundus mobilization on outcome after laparoscopic total fundoplication. J Gastrointest Surg. 2000;4(5):493-500.

18. Chrysos E, Tzortzinis A, Tsiaoussis J, Athanasakis $\mathrm{H}$, Vassilakis JS, Xynos E. Prospective randomized trial comparing Nissen to Nissen-Rossetti technique for laparoscopic fundoplication. Am J Surg. 2001;182(3):215-21.

19. Catarci M, Gentileschi P, Papi C, Carrara A, Marrese R, Gaspari AL. Evidence-based appraisal of antireflux fundoplication. Ann Surg. 2004;239(3):325-37.

20. Soper JN. Fundoplication and the short gastric vessels: divide and conquer. Ann Surg. 2002;235(2):171-3.

21. Gotley DC, Smithers BM, Menzies B, Branicki FJ, Rhodes M, Nathanson L. Laparoscopic Nissen fundoplication and postoperative dysphagia: can it be predicted? Ann Acad Med Singapore. 1996;25:646-9.

22. Hinder RA, Filipi CJ, Wetscher G, Neary P, DeMeester TR, Perdikis G. Laparoscopic Nissen fundoplication is an effective treatment for gastroesophageal reflux disease. Ann Surg. 1994;220(4):472-83.

23. Dallemagne B, Weerts JM, Jehaes C, Markiewicz S. Causes of failures of laparoscopic antireflux operations. Surg Endosc. 1996;10(3):305-10.

24. Aranha NC, Brandalise NA.Tratamento videolaparoscópico da esofagite de refluxo pela técnica “mista” (Nissen modificado). GED:1995:14:219-22.

25. Swanstrom LL, Pennings JL. Laparoscopic control of short gastric vessels. J Am Coll Surg. 1995;181:347-51.

26. Laycock WS, Trus TL, Hunter JG. New technology for the division of short gastric vessels during laparoscopic Nissen fundoplication: a prospective randomized trial. Surg Endosc. 1996;10(1):71-3.

27. Underwood RA, Dunnegan DL, Soper NJ. Prospective, randomized trial of bipolar electrosurgery vs ultrasonic coagulation for division of short gastric vessels during laparoscopic Nissen fundoplication. Surg Endosc. 1999;13(8):763-8.

28. Huntington TR, Danielson L. Variation in fundic dimensions with respect to short gastric vessel division in laparoscopic fundoplication. Surg Endosc. 
2001;15:76-9.

29. Patterson EJ, Herron DM, Hansen PD, Ramzi N, Standage BA, Swanström LL. Effect of an esophageal bougie on the incidence of dysphagia following Nissen fundoplication: a prospective, blinded, randomized clinical trial. Arch Surg. 2000;135(9):1055-61.

30. Novitsky YW, Kercher KW, Callery MP, Czerniach DR, Kelly JJ, Litwin DE. Is the use of a bougie necessary for laparoscopic Nissen fundoplication? Arch Surg. 2002;137(4):402-6.

31. Schauer P, Meyers W, Eubanks S, Norem R, Morris F, Theodore P. Mechanisms of gastric and esophageal perforations during laparoscopic Nissen fundoplication. Ann Surg. 1996;223(1):43-52.

32. Peters JH, DeMeester TR, Crookes P, Öberg S, de Vos Shoop M, Hagen LA, Bremner CG. The treatment of gastroesophageal reflux disease with laparoscopic Nissen fundoplication: prospective evaluation of 100 patients with “typical” symptoms. Ann Surg. 1998;228(1):40-50.
33. Paula AL. Fundoplicatura total laparoscópica no tratamento da doença do refluxo gastroesofageano. [Tese - Doutorado]. São Paulo: Faculdade de Medicina - Universidade de São Paulo;1997.

34. Coelho JCU, Wiederkehr JC, Campos ACL, Andrigueto PC, Pinho RV, Bonin EA. Complicações do tratamento laparoscópico da doença do refluxo gastroesofágico: experiência com 600 casos. Rev Col Bras Cir. 1999;26(4):237-42.

35. Carlson MA, Frantzides CT. Complications and results of primary minimally invasive antireflux procedures: a review of 10.735 reported cases. Am J Coll Surg. 2001;193(4):428-39.

36. Pastore R. Avaliação da hiatoplastia e válvula antirefluxo total no tratamento da doença do refluxo gastroesofágico: estudo comparativo pré e pósoperatório de aspectos manométricos e phmétricos e sua relação com a esofagite endocóspica [Tese Doutorado]. São Paulo: Universidade Federal de São Paulo, Escola Paulista de Medicina; 2005.

\section{Correspondence:}

José Francisco de Mattos Farah

R. Pascal, 778/151

04616-002 São Paulo - SP Brazil

josefarah@einstein.br
Conflict of interest: none

Financial source: none

Received: April 17, 2007

Review: June 19, 2007

Accepted: July 17, 2007

\section{How to cite this article}

Farah JFM, Del Grande JC, Goldenberg A, Martinez JC, Lupinacci RA, Matone J. Randomized trial of total fundoplication and fundal mobilization with or without division of short gastric vessels. A short-term clinical evaluation. Acta Cir Bras. [serial on the Internet] 2007 Nov-Dec;22(6). Available from URL: $\underline{\text { http://www.scielo.br/acb }}$ 